\title{
PENGARUH KUALITAS PELAYANAN TERHADAP KEPUASAN MASYARAKAT PADA PEMBUATAN KARTU PESERTA JAMINAN KESEHATAN NASIONAL (JKN) DI KANTOR BPJS KESEHATAN KOTA BOGOR
}

\section{EFFECT OF SERVICE QUALITY ON SATISFACTION COMMUNITY IN THE DEVELOPMENT OF PARTICIPANTS CARD NATIONAL HEALTH (JKN) AT HEALTH OFFICE OF BPJS BOGOR CITY}

\author{
Agus Mantri ${ }^{1 *}$, Abu Bakar Iskandar ${ }^{2}$, Irma Purnamasari ${ }^{3}$ \\ ${ }_{1}^{1}$ Jurusan Ilmu Administrasi Negara Fakultas Ilmu Sosial dan Ilmu Politik Universitas \\ Djuanda, Jl. Tol Ciawi No.1, Kotak Pos 35 Bogor 16770 \\ ${ }^{2}$ Jurusan Ilmu Administrasi Negara Fakultas Ilmu Sosial dan Ilmu Politik Universitas \\ Djuanda, Jl. Tol Ciawi No.1, Kotak Pos 35 Bogor 16770 \\ ${ }^{3}$ Jurusan Ilmu Administrasi Negara Fakultas Ilmu Sosial dan Ilmu Politik Universitas \\ Djuanda, Jl. Tol Ciawi No.1, Kotak Pos 35 Bogor 16770 \\ *Korespondensi: Agus Mantri, Email : agus.mantri@unida.ac.id
}

(Diterima oleh Dewan Redaksi: 01-08-2017)

(Dipublikasikan oleh Dewan Redaksi: 01-10-2017)

\begin{abstract}
The increasing number of enthusiasts accessing the BPJS card does not seem to be accompanied with the service of obtaining JKN card (National Health Insurance). Reality people start waiting in front of the office around 6 am just to get early queue. Not to mention the readiness of very minimal service, limited staff and counter and various facilities that do not support the comfort during the wait. Even every day is limited to 90 people. This shows that the quality of service on the manufacture of JKN card in BPJS office has not function properly. The purpose of this study is to know the influence between the quality of service to public satisfaction in the manufacture of JKN card in the office of BPJS Bogor City. The theory used in this research is using the service quality theory of Zeithaml, Parasuraman, \& Berry in Ratminto and Atik Septi Winarsih and also the theory of public satisfaction by Boediono which states that to measure a quality of service and a community satisfaction can be measured through five dimensions namely: Tangibles, Empathy, Reliability, Responsiveness, and Assurance (TERRA). The method used is associative with Rank Spearman correlation test. From the correlation coefficient results there are two indicators of the level of influence is very strong that is serving properly and have knowledge while the level of influence on indicators to complete the needs is very low. The results of the contribution of service quality variable to the variable of community satisfaction by $54 \%$ are influenced or determined by BPJS service quality variable by $46 \%$. So it can be concluded that Based on the results of associative statistical hypothesis that H0: $p=0$ (no relationship) means there is no effect of service quality on community satisfaction.
\end{abstract}

Keywords: Quality of service BPJS, JKN-BPJS program, and community satisfaction card maker JKN-BPJS. 


\begin{abstract}
ABSTRAK
Meningkatnya jumlah peminat mengakses kartu BPJS, nampaknya belum diiringi dengan pelayanan mendapatkan kartu JKN (Jaminan Kesehatan Nasional). Kenyataan masyarakat mulai menunggu di depan kantor sekitar jam 6 pagi hanya untuk mendapatkan antrian awal. Belum lagi kesiapan pelayanan yang sangat minim, terbatasnya petugas dan loket serta berbagai fasilitas yang tidak mendukung kenyamanan selama menunggu. Bahkan setiap hari hanya dibatasi sampai 90 orang. Hal ini menunjukkan bahwa kualitas pelayanan pada pembuatan kartu JKN di kantor BPJS belum berfungsi baik. Tujuan penelitian ini adalah mengetahui adanya pengaruh antara kualitas pelayanan terhadap kepuasan masyarakat dalam pembuatan kartu JKN di kantor BPJS Kota Bogor. Teori yang digunakan dalam penelitian ini yaitu dengan menggunakan teori kualitas pelayanan dari Zeithaml, Parasuraman, \& Berry dalam Ratminto dan Atik Septi Winarsih dan juga teori kepuasan masyarakat oleh Boediono yang menyatakan bahwa untuk mengukur suatu kualitas pelayanan dan suatu kepuasan masyarakat dapat di ukur melalui lima dimensi yaitu : Tangibles, Empathy, Reliability, Responsiveness, dan Assurance (TERRA). Metode yang digunakan adalah Asosiatif dengan uji korelasi Rank Spearman. Dari hasil koefisian korelasi terdapat dua indikator tingkat pengaruh sangat kuat yaitu melayani dengan benar dan memiliki pengetahuan sedangkan tingkat pengaruh pada indikator melengkapi kebutuhan adalah sangat rendah. Hasil penelitian kontribusi variabel kualitas pelayanan terhadap variabel kepuasan masyarakat sebesar 54\% sisanya dipengaruhi atau ditentukan oleh variabel kualitas petugas pelayanan BPJS sebesar 46\%. Maka dapat disimpulkan bahwa Berdasarkan hasil hipotesa statistic asosiatif bahwa $\mathrm{HO}: \mathrm{p}=0$ (tidak ada hubungan) artinya tidak terdapat pengaruh kualitas pelayanan terhadap kepuasan masyarakat.
\end{abstract}

Kata Kunci: Kualitas pelayanan BPJS, program JKN-BPJS, dan kepuasan masyarakat pembuat kartu JKN-BPJS.

Agus Mantri, 2017, Pengaruh Kualitas Pelayanan Terhadap Kepuasan Masyarakat Pada Pembuatan Kartu Peserta Jaminan Kesehatan Nasional (JKN) di Kantor BPJS Kesehatan Kota Bogor. Jurnal Governansi. 


\section{PENDAHULUAN}

Dalam UU No. 25 tahun 2009 tentang pelayanan publik, dijelaskan masyarakat berhak mendapatkan pelayanan yang berkualitas sesuai dengan asas dan tujuan pelayanan (pasal 18).

Keberhasilan suatu bangsa dapat dilihat dari bagaimana tercapainya tujuan pemerintahan pada saat ini, yaitu dengan memberikan service yang baik kepada masyarakat. Permasalahan pelayanan publik di Indonesia saat ini masih menemui berbagai permasalahan yang sangat klasik diantaranya pelayanan yang berbelit-belit, tidak adanya kejelasan dari prosedur pelayanan di suatu instansi pemerintah, masih belum diterapkannya standar pelayanan minimal, tidak adanya kejelasan biaya yang tertera sehingga hal ini dapat menyebabkan maraknya korupsi, kolusi dan nepotisme (KKN) serta masih banyaknya pegawai yang tidak beriorientasi kepada tugas, pokok dan fungsi (tupoksi) nya sebagai pemberi layanan publik hingga mengabaikan masyarakat penerima layanan yang ingin mendapat informasi.

Meningkatnya permasalahan yang terjadi dalam penanganan kebakaran, khususnya di Kota Bogor dari tahun ke tahun. Menyebabkan tuntutan masyarakat terhadap pelayanan pemadam kebakaran untuk memberikan pelayanan yang diinginkan masyarakat.

Berdasarkan jumlah kejadian bencana baik kebakaran maupun bencana alam lainnya yang ada di Kota Bogor terus meningkat, dari angka 2013 sebanyak 137 kejadian menjadi 144 kejadian ditahun 2014, di 2015 sebanyak 123 dan di 2016 sebanyak 133 kasus. Diharapkan dengan adanya penelitian ini maka dapat memberikan masukan bagi berbagai pihak khususnya kepada penyelenggara jasa Pemadam Kebakaran Kota Bogor sehingga dapat dijadikan referensi untuk meningkatkan mutu pelayanan jasa sosial kemasyarakatan sesuai dengan harapan masyarakat.

Sebagai contoh rekapan kejadaian kebakaran Tahun 2015

TABEL 1

DATA KEBAKARAN

\begin{tabular}{|c|c|c|c|c|c|}
\hline $\begin{array}{l}\text { Thn } \\
201 \\
5\end{array}$ & $\begin{array}{c}\text { Jumlah } \\
\text { Kebaka } \\
\text { ran }\end{array}$ & $\begin{array}{c}\text { Juml } \\
\text { ah } \\
\text { Keba } \\
\text { kara } \\
\text { n }\end{array}$ & $\begin{array}{l}\text { Yang } \\
\text { terta } \\
\text { ngan } \\
\text { i } 100 \\
\%\end{array}$ & $\begin{array}{l}\text { Yang } \\
\text { tidak } \\
\text { tertan } \\
\text { gani } \\
\text { denga } \\
\text { n baik } \\
\text { ( } \\
\text { kerugi } \\
\text { an } \\
\text { besar } \\
\text { ) }\end{array}$ & $\begin{array}{c}\text { Keteranga } \\
\mathrm{n}\end{array}$ \\
\hline 1 & Januari & 4 & 2 & 2 & Kabupaten \\
\hline 2 & Febuari & 3 & 3 & & \\
\hline 3 & Maret & 2 & 2 & & \\
\hline 4 & April & 4 & 2 & 2 & Kabupaten \\
\hline 5 & Mei & 7 & 4 & 3 & \\
\hline 6 & Juni & 7 & 5 & 2 & TKP Jauh \\
\hline 7 & Juli & 6 & 6 & & \\
\hline 8 & Agustus & 16 & 15 & & \\
\hline 9 & $\begin{array}{l}\text { Septem } \\
\text { ber }\end{array}$ & 1 & 1 & 1 & $\begin{array}{l}\text { Rumah } \\
\text { kayu }\end{array}$ \\
\hline 10 & Oktober & 6 & 6 & & \\
\hline 11 & $\begin{array}{l}\text { Nopem } \\
\text { ber }\end{array}$ & 4 & 4 & 1 & 1 Korban \\
\hline 12 & $\begin{array}{l}\text { Desemb } \\
\text { er }\end{array}$ & 4 & 3 & & $\begin{array}{l}\text { meninggal } \\
\text { karena } \\
\text { terjebak } \\
\text { api pada } \\
\text { saat } \\
\text { tertidur }\end{array}$ \\
\hline
\end{tabular}

(Rekapitulasi data kebakaran 2015)

Selanjutnya menurut Kepmenpan No. 63/KEP/M.PAN/7/2003, pelayanan publik adalah segala kegiatan pelayanan yang dilaksanakan oleh penyelenggara pelayanan publik sebagai upaya pemenuhan kebutuhan penerima layanan maupun pelaksanaan ketentuan peraturan perundang-undangan. 


\section{MATERI DAN METODE}

Menurut Zeithaml, dkk dalam Hardyansah, 2011: 46 Responsivitas dijabarkan menjadi beberapa indikator, seperti meliputi:

1. Merespon setiap pelanggan/ pemohon yang ingin mendapatkan pelayanan Indikator Ini mencakup sikap dan komunikasi yang baik dari para penyedia layanan.

2. Petugas/ aparatur melakukan pelayanan dengan cepat Pelayanan dengan cepat ini berkaitan dengan kesigapan dan ketulusan penyedia layanan dalam menjawab setiap pertanyaan dan memenuhi permintaan pelanggan.

3. Petugas/ aparatur melakukan pelayanan dangan tepat, Yaitu, tidak terjadi kesalahan dalam melayani, artinya pelayanan yang diberikan sesuai dengan keinginan masyarakat sehingga tidak ada yang merasa dirugikan atas pelayanan yang didapatnya.

4. Petugas/ aparatur melakukan pelayanan dengan cermat, Berarti penyedia layanan harus selalu fokus dan sungguhsungguh dalam memberikan pelayanan kepada masyarakat.

5. Petugas/ aparatur melakukan pelayanan dengan waktu yang tepat Waktu yang tepat berarti pelaksanaan pelayanan kepada masyarakat dapat diselesaikan dalam waktu yang telah ditentukan sehingga dapat memberikan kepastian pelayanan kepada masyarakat.

6. Semua keluhan pelanggan direspon oleh petugas Bahwa setiap penyedia layanan harus menyediakan akses kepada masyarakat untuk dapat menyampaikan keluhannya dan dapat dicarikan solusi yang terbaik. (Zeithmal, dkk dalam Hardyansah, 2011:46).

Tipe penelitian yang digunakan merupakan tipe penelitian deskriptif untuk memberikan gambaran secara jelas melalui masalah yang akan diteliti peneliti. Penelitian deskriptif adalah penelitian yang dilakukan untuk mengetahui nilai variabel mandiri, baik satu variabel atau lebih (independen) tanpa membuat perbandingan, atau menghubungkan antara variabel yang lain.

\section{Unit Analisis}

Unit analisis adalah sumber informasi mengenai variabel yang akan diolah pada tahap analisis data, unit analisis dapat berupa individu, kelompok atau organisasi. Dalam penelitian ini menggunakan penelitian kuantitatif dimana penelitian ini mempunyai subyek penelitian yaitu populasi, sampel dan sampling. Menurut Sugiyono:

a. Populasi

Adalah wilayah generalisasi terdiri atas obyek/ subyek yang mempunyai kualitas dan karakteristik tertentu. Sugiyono (2008:115)

b. Sampel

Adalah sebagian dari jumlah dan karakteristik yang dimiliki oleh populasi tersebut. Sugiyono (2008:116).

Sebagai unit analisis, penelitian ini peneliti menggunakan subjek populasi yaitu semua pegawai lapangan Aparatur Sipil Negara (ASN) pada Pemadam Kebakaran Kota Bogor sebanyak 50 orang dengan teknik sampling ke semua pegawai Pemadam Kebakaran Kota Bogor.

\section{Teknik Pengumpulan Data}

Penelitian ini dilakukan dengan metode deskriptif kuantitatif. Untuk memperoleh data, sumber data yang digunakan dalam penelitian ini adalah:

a. Wawancara

Wawancara dilakukan kepada seluruh petugas dilapangan UPTD Pemadam Kebakaran Kota Bogor. Maksud wawancara seperti ditegaskan oleh Lincoln dan Guba dalam J.Moleong 2007; 186, antara lain mengkontruksi mengenai orang, kajadian organisasi, perasaan, motivasi dan lainlain. 
b. Observasi

Observasi adalah teknik memperolh data dengan cara meneliti dan mengamati langsung pada sumber data yang akan dianalisis mengenai Responsivitas Aparatur Sipil Negara (ASN) dalam melayani pemadaman kebakaran di Kota Bogor.

c. Kuesioner

Pada penelitian ini penulis menggunakan teknik pengumpulan data kuesioner (angket). Menurut Sugiyono (2010:199) "Kuesioner merupakan teknik pengumpulan data dengan cara memberi seperangkat pertanyaan atau pernyataan tertulis kepada responden untuk menjawabnya.

Menurut Sugiyono (2008:135), skala Likert adalah yang mempunyai gradasi yang sangat positif sampai negatif dan digunakan untuk mengukur persepsi seseorang atau kelompok, juga untuk menganalisa kuantitatif dengan menggunakan skor untuk pertanyaanpertanyaan tersebut dengan klasifikasi penilaian sebagai berikut:

Tabel 2 Klasifikasi Jawaban Skala Likert

\begin{tabular}{|c|c|c|}
\hline Jawaban & Klasifikasi & Skor \\
\hline A & Sangat Baik & 5 \\
\hline B & Baik & 4 \\
\hline C & Cukup Baik & 3 \\
\hline D & Kurang Baik & 2 \\
\hline E & Tidak Baik & 1 \\
\hline
\end{tabular}

\section{Teknik Analisis Data}

Analisis data dalam penelitian kuantitatif, dilakukan pada saat pengumpulan data berlangsung, dan setelah selesai pengumpulan data dalam periode tertentu. Pada saat wawancara, peneliti sudah melakukan analisis terhadap jawaban yang diwawancarai. Bila jawaban yang diwawancarai setelah dianalisis terasa belum memuaskan maka peneliti akan melanjutkan pertanyaan lagi, sampai tahap tertentu, diperoleh data yang dianggap kredibel.

Weight Inear Score :

$$
\begin{aligned}
& M=\text { Rata- } \text { rata } \\
& \text { F= Frekuensi } \\
& \text { N= Sampel } / \text { Populasi }
\end{aligned}
$$

\section{Lokasi Penelitian}

Penelitian ini dilakukan di UPTD Pemadam Kebakaran Kota Bogor yang beralamat di jalan Raya Pajajaran No 1 Bogor Timur. Alasan penulis melakukan penelitian di UPTD Pemadam kebakaran Kota Bogor karena posko tersebut merupakan salah satu penyelenggara pelayanan jasa kebencanaan yang terjadi di Kota Bogor.

\section{PEMBAHASAN}

Secara geografis Kota Bogor terletak diantara 106' 48' BT dan 6' 26' LS, kedudukan geografis Kota Bogor di tengahtengah wilayah Kabupaten Bogor serta lokasinya sangat dekat dengan Ibukota Negara, merupakan potensi yang strategis bagi perkembangan dan pertumbuhan ekonomi dan jasa, pusat kegiatan nasional untuk industri, perdagangan, transportasi, komunikasi, dan pariwisata.

Luas Wilayah Kota Bogor sebesar 11.850 Ha terdiri dari 6 kecamatan dan 68 kelurahan. Dengan jumlah penduduk 1.030.720 dengan kepadatan penduduk 124 jiwa/km2, ini memperlihatkan bahwa kepadatan permukiman yang ada diKota Bogor dan dilihat dari pembagian wilayah perkecamatan yang cukup jauh antara (seperti Kecamatan Tanah Sareal) yang cukup jauh dijangkau oleh armada Pemadam Kebakaran. Sedangkan diwilayah Kecamatan Bogor Selatan, Bogor Barat dan 
Bogor Tengah yang memiliki permukiman yang sangat padat sehingga sulitnya akses jalan untuk petugas pemadam kebakaran.

Berdasarkan UU No 23 Tahun 2014 tentang Pemerintah Daerah ( Revisi UU No 32 Tahun 2004 ) UPTD Pemadam Kebakaran \& Penanggulangan Bencana Kota Bogor yang berada dibawah pengawasan Dinas Pengawasan dan Permukiman Kota Bogor.

Adapun Visi UPTD Pemadam Kebakaran \& Penanggulangan Bencana Kota Bogor adalah :

“ Terselenggaranya perlindungan kepada masyarakat dari ancaman bahaya kebakaran melalui terciptanya sistem pencegahan dan penanggulangan kebakaran yang handal “

Misi :

1. Melaksanakan usaha pencegahan ;

2. Melaksanakan penanggulangan kebakaran ;

3. Menyelenggarakan penyuluhan;

4. Mengadakan pemeliharaan dan pengadaan sarana dan prasarana ;

5. Melaksanakan koordinasi internal dan eksternal.

\subsubsection{Tugas dan Fungsi Tugas Pokok:}

Melaksanakan sebagian kewenangan Daerah dalam bidang pencegahan dan penanggulangan kebakaran yang meliputi : pencegahan, pembinaan dan penyuluhan, dan pengendalin operasional.

\section{Fungsi :}

1. Merumuskan kebijakan teknis bidang pencegahan dan penanggulangan kebakaran

2. Melaksanakan tugas teknis operasional dibidang pencegahan dan penanggulangan kebakaran

3. Melaksanakan pelayanan teknis administratif meliputi : administrasi umum dan kepegawaian, perencanaan dan pengembangan serta administrasi keuangan.

\subsection{Hasil dan Analisis Data}

Dalam mengolah data yang telah diperoleh, peneliti menggunakan teknik yaitu dengan cara menganalisinya berdasarkan data yang ada. Data yang diperoleh terdiri dari tinjauan pustaka dan contoh kasus yang ada. Kemudian dari hasil data tersebut akan diuraikan satu persatu dimensi beserta indikator yang penulis ajukan dengan menggunakan teknik analisis data kuantitatif. Data yang terkumpul dari tinjauan pustaka dan contoh kasus akan penulis deskripsikan, sehingga diketahui bagaimana hasil analisis terhadap variabel tersebut.

\subsection{Pembahasan Responsivitas ASN dalam melayani Pemadam Kebakaran di Kota Bogor}

Pelayanan yang baik dan berkualitas merupakan faktor yang sangat diperlukan bagi setiap organisasi terutama organisasi yang dalam bidang jasa dalam menghadapi tantangan persaingan yang sangat ketat. UPTD Pemadam Kebakaran termasuk salah satu lembaga yang dimiliki dan dikelola oleh pemerintah di Indonesia.

Dalam menjalankan tugasnya UPTD pemadam kebakaran harus mengutamakan pelayanan kepada masyarakat pengguna jasanya. Hal ini sejalan dengan tujuan utama dari organisasi pemerintah yaitu memberikan pelayanan yang sebaikbaiknya kepada masyarakat (public service) di berbagai bidang termasuk bidang jasa pelayanan umum di Indonesia.

Dalam penelitian ini, penulis menetepkan fokus penelitian pada kualitas pelayanan pada UPTD pemadam kebakaran. Untuk mengetahui mengenai kualitas pelayanan tersebut, dalam penelitian ini penulis menggunakan dimensi kualitas pelayanan yang mengacu pada pendapat yang dikemukakan oleh Zeithmal, yaitu:

1. Kemampuan merespon setiap pelanggan

2. Kecepat melayani

3. Ketepatan melayani 
4. Kecermatan melayani

5. Ketepatan waktu melayani

6. Kemampuan menanggapi keluhan

Untuk lebih jelasnya, berikut ini penulis menyajikan hasil pembahasan kualitas pelayanan UPTD Pemadam Kebakaran di Kota Bogor, yaitu:

\subsubsection{Kemampuan Aparatur Sipil Negara (ASN) dalam merespon laporan masyarakat}

Merespon setiap pelanggan/ pemohon yang ingin mendapatkan pelayanan. Indikator ini mencakup sikap yang memiliki dua indikator yaitu: kemampuan ASN dalam merespon laporan dari masyarakat dan kemampuan untuk menanggapi respon dari masyarakat yang baik dari petugas pelayanan pemadam kebakaran ketika ada masyarakat yang membutuhkan pelayanan tersebut.

Tabel 3

Kemampuan ASN dalam Merespon Laporan dari Masyarakat

\begin{tabular}{|l|c|c|c|c|}
\hline $\begin{array}{c}\text { Alternatif } \\
\text { Jawaban }\end{array}$ & (f) & $\mathbf{x}$ & $\mathbf{f ( x )}$ & $\begin{array}{c}\mathbf{M = \Sigma f} \\
(\mathbf{x}) / \mathbf{n}\end{array}$ \\
\hline Sangat Mampu & 6 & 5 & 30 & \\
\hline Mampu & 29 & 4 & 116 & \\
\hline Cukup Mampu & 9 & 3 & 27 & \\
\hline Kurang Mampu & 6 & 2 & 12 & \\
\hline Tidak mampu & - & 1 & 1 & \\
\hline Jumlah & $\mathbf{5 0}$ & & $\mathbf{1 8 6}$ & $\mathbf{3 . 7 2}$ \\
\hline
\end{tabular}

Berdasarkan hasil perhitungan diatas menunjukan bahwa dari 50 responden yang menjawab Sangat Mampu 6 reponden, Mampu 29 Responden, Cukup Mampu 9 Responden, Kurang Mampu 6 Responden, dan Tidak Mampu tidak ada. Berdasarkan pembobotan skala nilai diperoleh 3.72 dimana angka tersebut berada pada kriteria Baik artinya dalam merespon laporan dari masyarakat pada saat menerima laporan kejadian bencana diterima dengan baik.
Tabel 4

\section{Kemampuan ASN dalam menerima respon dari Masyarakat}

\begin{tabular}{|l|c|c|c|c|}
\hline $\begin{array}{c}\text { Alternatif } \\
\text { Jawaban }\end{array}$ & (f) & $\mathbf{x}$ & $\mathbf{f ( x )}$ & $\begin{array}{c}\mathbf{M}=\mathbf{\sum f ( x )} \\
/ \mathbf{n}\end{array}$ \\
\hline Sangat Baik & 10 & 5 & 50 & \\
\hline Baik & 22 & 4 & 88 & \\
\hline Cukup Baik & 18 & 3 & 54 & \\
\hline Kurang Baik & - & 2 & 2 & \\
\hline Tidak Baik & - & 1 & 1 & \\
\hline Jumlah & $\mathbf{5 0}$ & & $\mathbf{1 9 5}$ & $\mathbf{3 , 9 0}$ \\
\hline
\end{tabular}

Berdasarkan hasil perhitungan diatas menunjukan bahwa dari 50 responden yang menjawab Sangat Baik 10 reponden, Baik 22 Responden, Cukup Baik 18 Responden, Kurang Mampu Tidak Ada, dan Tidak Mampu tidak ada. Berdasarkan pembobotan skala nilai diperoleh 3,90 dimana angka tersebut berada pada kriteria Baik artinya Respon masyarakat terhadap pemadam kebakaran sudah baik.

4.4.2 Kecepatan melayani masyarakat pada saat menerima laporan bencana dari masyarakat

Petugas/ aparatur melakukan pelayanan dengan cepat. Pelayanan dengan cepat ini berkaitan dengan kesigapan petugas dalam memberikan pelayanan pemadam kebakaran sesuai dengan permintaan masyarakat, dimensi ini mempunyai satu indikator yaitu Tanggapan Masyarakat terhadap Kecepatan Pelayanan yang diberikan oleh Petugas Pemadam Kebakaran. Dari hasil penelitian ini mendapatkan hasil sebagai berikut: 
Tabel 5

Tanggapan Responden terhadap Kecepatan Melayani

$(n=50)$

\begin{tabular}{|l|c|c|c|c|}
\hline $\begin{array}{l}\text { Alternatif } \\
\text { Jawaban }\end{array}$ & (f) & $\mathbf{x}$ & $\mathbf{f ( x )}$ & $\begin{array}{l}\mathbf{M = \sum f} \\
(\mathbf{x}) / \mathbf{n}\end{array}$ \\
\hline $\begin{array}{l}\text { Langsung } \\
\text { saat itu juga }\end{array}$ & 10 & 5 & 50 & \\
\hline $\begin{array}{l}\text { 10 Menit } \\
\text { Kemudian }\end{array}$ & 34 & 4 & 136 & \\
\hline 15 Menit & 3 & 3 & 9 & \\
\hline 20 Menit & 3 & 2 & 6 & \\
\hline $\begin{array}{l}\text { Lebih dari 30 } \\
\text { Menit }\end{array}$ & - & 1 & 1 & \\
\hline Jumlah & $\mathbf{5 0}$ & & $\mathbf{2 0 2}$ & $\mathbf{4 , 0 4}$ \\
\hline
\end{tabular}

Berdasarkan hasil perhitungan diatas menunjukan bahwa dari 50 responden yang menjawab Langsung saat itu juga 10 reponden, 10 Menit Kemudian 34 Responden, 15 Menit 3 Responden, 20 Menit 3 Responden, dan Lebih dari 30 Menit tidak ada. Berdasarkan pembobotan skala nilai diperoleh 4,04 dimana angka tersebut berada pada kriteria Baik itu artinya dalam kecepatan dalam melayani masyarakat pada saat menerima laporan kejadian bencana dijalankan dengan baik.

\subsubsection{Ketepatan dalam melayani masyarakat 4.4 pada saat penanganan bencana}

Petugas/aparatur melakukan pelayanan dengan tepat. Pada indikator ini dimaksudkan bahwa tidak terjadi kesalahan dalam melayani, artinya pelayanan yang diberikan sesuai dengan keinginan masyarakat dan tidak terjadi kekeliruan dalam pelaksanaan pemberian pelayanan jasa pemadam kebakaran. Dalam dimensi ini mempunyai satu indikator yaitu Ketepatan dalam melayani masyarakat dapat dilihat dari hasil penelitian berikut ini:
Tabel 6

Tanggapan Responden terhadap Ketepatan Melayani

\begin{tabular}{|l|c|c|c|c|}
\hline $\begin{array}{l}\text { Alternatif } \\
\text { Jawaban }\end{array}$ & (f) & $\mathbf{x}$ & $\mathbf{f ( x )}$ & $\mathbf{M}=\sum \mathbf{f}(\mathbf{x}) / \mathbf{n}$ \\
\hline $\begin{array}{l}\text { Sangat } \\
\text { Tepat }\end{array}$ & 18 & 5 & 90 & \\
\hline Tepat & 26 & 4 & 104 & \\
\hline Cukup Tepat & 6 & 3 & 18 & \\
\hline $\begin{array}{l}\text { Kurang } \\
\text { Tepat }\end{array}$ & - & 2 & 2 & \\
\hline Tidak Tepat & - & 1 & 1 & \\
\hline Jumlah & $\mathbf{5 0}$ & & $\mathbf{2 1 5}$ & $\mathbf{4 . 3 0}$ \\
\hline
\end{tabular}

Berdasarkan hasil perhitungan diatas menunjukan bahwa dari 50 responden yang menjawab Sangat Tepat 18 reponden, Tepat 26 Responden, Cukup Tepat6 Responden, Kurang TepatTidak Ada, dan Tidak Tepat tidak ada. Berdasarkan pembobotan skala nilai diperoleh 4,30 dimana angka tersebut berada pada kriteria Sangat Baik itu artinya dalam ketepatan dalam mengetahui jenis apa saja yang terbakardiketahui pada saat menerima laporan kejadian kebakarandijalankan dengan baik.

\section{Kecermatan dalam melayani masyarakat pada saat penanganan bencana}

Petugas/aparatur melakukan pelayanan dengan cermat. Hal ini merupakan artian bahwa petugas pelayanan pemadam kebakaran dalam pemberian jasa tersebut sangat fokus dan bersungguh-sungguh dalam memberikan pelayanan kepada masyarakat. Dalam dimensi ini mempunyai satu indikator yaitu kecermatan dalam melayani masyarakat dalam penanganan bencana, ini bisa dilihat dari hasil berikut ini: 
Tabel 7

Tanggapan Responden terhadap Kecermatan Melayani

\begin{tabular}{|l|c|c|c|c|}
\hline $\begin{array}{l}\text { Alternatif } \\
\text { Jawaban }\end{array}$ & (f) & $\mathbf{x}$ & $\begin{array}{c}\mathbf{f}(\mathbf{x} \\
\mathbf{j}\end{array}$ & $\begin{array}{c}\mathbf{M}=\mathbf{\sum} \\
(\mathbf{x}) / \mathbf{n}\end{array}$ \\
\hline $\begin{array}{l}\text { Sangat } \\
\text { Cermat }\end{array}$ & 12 & 5 & 60 & \\
\hline Cermat & 20 & 4 & 80 & \\
\hline $\begin{array}{l}\text { Cukup } \\
\text { Cermat }\end{array}$ & 18 & 3 & 54 & \\
\hline $\begin{array}{l}\text { Kurang } \\
\text { Cermat }\end{array}$ & - & 2 & 2 & \\
\hline Tidak Cermat & - & 1 & 1 & \\
\hline Jumlah & $\mathbf{5 0}$ & & $\mathbf{1 9}$ & $\mathbf{3 , 9 4}$ \\
\hline
\end{tabular}

Berdasarkan hasil perhitungan diatas menunjukan bahwa dari 50 responden yang menjawab Sangat Cermat 12 reponden, Cermat 20 Responden, Cukup Cermat 18 Responden, Kurang Cermat Tidak Ada, dan Tidak Cermat tidak ada. Berdasarkan pembobotan skala nilai diperoleh 3,94 dimana angka tersebut berada pada kriteria Baik itu artinya dalam kecermatan dalam menghadapi kebakaran sudah baik keterampilan dan pelatihan petugas pemadam kebakaran.

\subsubsection{Ketepatan waktu dalam melayani masyarakat dengan respontime yank.4.6} ada

Petugas/ aparatur melakukan pelayanan dengan waktu yang tepat. Waktu yang tepat berarti petugas pemadam kebakaran dalam hal ini dapat memberikan kepastian penanganan pelayanan pemadam kebakaran kepada masyarakat. Ketepatan waktu dalam penanganan bencana ini berkaitan dengan berkurangnya kerugian pada saat pasca bencana. Dimensi ini mempunyai satu indikator yaitu ketepatan waktu dalam memberikan pelayanan pada saat terjadinya bencana. Dari hasil penelitian dapat dilihat sebagai berikut:
Tabel 8

\section{Tanggapan Responden terhadap Ketepatan Waktu Melayani}

\begin{tabular}{|l|c|c|c|c|}
\hline $\begin{array}{l}\text { Alternatif } \\
\text { Jawaban }\end{array}$ & (f) & $\mathbf{x}$ & $\mathbf{f ( x}$ & $\mathbf{M}=\boldsymbol{\Sigma f}(\mathbf{x}) / \mathbf{n}$ \\
\hline $\begin{array}{l}\text { Sangat } \\
\text { Tepat }\end{array}$ & 6 & 5 & 30 & \\
\hline Tepat & 11 & 4 & 44 & \\
\hline $\begin{array}{l}\text { Cukup } \\
\text { Tepat }\end{array}$ & 33 & 3 & 13 & \\
\hline $\begin{array}{l}\text { Kurang } \\
\text { Tepat }\end{array}$ & - & 2 & 2 & \\
\hline Tidak Tepat & - & 1 & 1 & \\
\hline Jumlah & $\mathbf{5}$ & & $\mathbf{2 0}$ \\
$\mathbf{0}$ & & $\mathbf{9}$ & $\mathbf{4 . 1 8}$ \\
\hline
\end{tabular}

Berdasarkan hasil perhitungan diatas menunjukan bahwa dari 50 responden yang menjawab Sangat Tepat 6 reponden, Tepat 11 Responden, Cukup Tepat 33 Responden, Kurang Tepat Tidak Ada, dan Tidak Tepat tidak ada. Berdasarkan pembobotan skala nilai diperoleh 4.18 dimana angka tersebut berada pada kriteria Baik itu artinya dalam ketepatan waktu dalam penanggulangan bencana khususnya kebakaran sudah baik dilaksanakan demi meminimalisir kerugian baik secara material maupun jiwa.

\section{Kemampuan menanggapi keluhan ketidakpuasan masyarakat}

Semua keluhan pelanggan direspon oleh petugas. Bahwa setiap petugas pemadam kebakaran harus menyediakan akses kepada masyarakat untuk dapat menyampaikan keluhan yang dialaminya. Dimensi inipun mempunyai satu indikator yaitu kemampuan dalam menanggapi keluhan/ ketidakpuasan masyarakat dalam pelayanan pemadam kebakaran. Dari hasil penelitian dapat dilihat sebagai berikut: 
Tabel 9

Sikap Petugas terhadap Menanggapi Keluhan Masyarakat

\begin{tabular}{|c|c|c|c|c|}
\hline $\begin{array}{l}\text { Alternatif } \\
\text { Jawaban }\end{array}$ & (f) & $\mathbf{x}$ & $f(x)$ & $\begin{array}{c}M=\sum f( \\
x) / n\end{array}$ \\
\hline $\begin{array}{l}\text { Sangat } \\
\text { Mampu }\end{array}$ & 6 & 5 & 30 & \\
\hline Mampu & 28 & 4 & 112 & \\
\hline $\begin{array}{l}\text { Cukup } \\
\text { Mampu }\end{array}$ & 16 & 3 & 48 & \\
\hline $\begin{array}{l}\text { Kurang } \\
\text { Mampu }\end{array}$ & - & 2 & 2 & \\
\hline $\begin{array}{l}\text { Tidak } \\
\text { mampu }\end{array}$ & - & 1 & 1 & \\
\hline Jumlah & $\begin{array}{l}5 \\
0\end{array}$ & & 193 & 3.86 \\
\hline
\end{tabular}

Berdasarkan hasil perhitungan diatas menunjukan bahwa dari 50 responden yang menjawab Sangat Mampu 6 reponden, Mampu 28 Responden, Cukup Mampu 16 Responden, Kurang Mampu Tidak Ada, dan Tidak Mampu tidak ada. Berdasarkan pembobotan skala nilai diperoleh 3.86 dimana angka tersebut berada pada kriteria Baik artinya dalam menanggapi keluhan dan ketidak puasan masyarakat petugas pemadam kebakaran dituntut untuk terus meningkatkan keterampilan dalam melayani masyarakat.

Dengan adanya dimensi pelayanan diatas, penulis menyimpulkan, bahwa dalam melaksanakan pelayanan publik berdasarkan dimensi pelayanan yaitu :

1. Kemampuan merespon setiap pelanggan

2. Kecepatan melayani

3. Ketepatan melayani

4. Kecermatan melayani

5. Ketepatan waktu melayani

6. Kemampuan menanggapi keluhan

\section{Kemampuan Aparatur Sipil Negara (ASN) dalam merespon laporan masyarakat}

Merespon setiap pelanggan/pemohon yang ingin mendapatkan pelayanan. Indikator ini mencakup sikap yang memiliki dua indikator yaitu : kemampuan ASN dalam merespon laporan dari masyarakat dan kemampuan untuk menanggapi respon dari masyarakat yang baik dari petugas pelayanan pemadam kebakaran ketika ada masyarakat yang membutuhkan pelayanan tersebut.

\section{Rekapitulasi Responsivitas ASN dalam Melayani Pemadam Kebakaran}

\begin{tabular}{|c|c|c|c|}
\hline No & Resoponsivitas & $\begin{array}{l}\text { Skor } \\
\text { / } \\
\text { Nilai }\end{array}$ & $\begin{array}{l}\text { Kriteria } \\
\text { Penafsiran }\end{array}$ \\
\hline 1 & $\begin{array}{l}\text { kemampuan } \\
\text { Aparatur Sipil } \\
\text { Negara ( ASN ) } \\
\text { dalam } \\
\text { merespon } \\
\text { laporan } \\
\text { masyarakat }\end{array}$ & 3.72 & Baik \\
\hline 2 & $\begin{array}{l}\text { waktu yang } \\
\text { diperlukan dari } \\
\text { mulai } \\
\text { mendapat } \\
\text { laporan } \\
\text { kebakaran } \\
\text { sampai ke } \\
\text { tindak } \\
\text { lanjutkeberang } \\
\text { katan armada } \\
\text { ( Respon Time ) }\end{array}$ & 4,08 & Baik \\
\hline 3 & $\begin{array}{l}\text { Ketepatan } \\
\text { dalam } \\
\text { memverifikasi } \\
\text { jenis kejadian } \\
\text { kebakaran } \\
\text { sehingga tahu } \\
\text { penanganan } \\
\text { seperti apa } \\
\text { yang akan }\end{array}$ & 4.04 & Baik \\
\hline
\end{tabular}




\begin{tabular}{|c|c|c|c|}
\hline & dijalankan & & \\
\hline 4 & $\begin{array}{l}\text { Kecermatan } \\
\text { dalam } \\
\text { pemadaman } \\
\text { kebakaran, } \\
\text { sehingga dapat } \\
\text { meminimalisir } \\
\text { kerugian baik } \\
\text { secara jiwa } \\
\text { maupun harta }\end{array}$ & 3.94 & Baik \\
\hline 5 & $\begin{array}{l}\text { Ketepatan } \\
\text { waktu dalam } \\
\text { Pemadaman } \\
\text { Kebakaran }\end{array}$ & 4.18 & Baik \\
\hline 6 & $\begin{array}{l}\text { Menanggapi } \\
\text { ketidakpuasan } \\
\text { masyarakat } \\
\text { terhadap } \\
\text { pelayanan } \\
\text { pemadam } \\
\text { kebakaran }\end{array}$ & 3.86 & Baik \\
\hline \multirow[t]{2}{*}{7} & $\begin{array}{l}\text { Respon } \\
\text { masyarakat } \\
\text { terhadap } \\
\text { pelayanan } \\
\text { pemadam } \\
\text { kebakaran }\end{array}$ & 3.90 & Baik \\
\hline & $\begin{array}{c}\text { Jumlah rata- } \\
\text { rata }\end{array}$ & 3,96 & Baik \\
\hline
\end{tabular}

\section{KESIMPULAN DAN IMPLIKASI}

Dengan melihat hasil penelitian penulis, maka dapat ditarik kesimpulan bahwa dalam responsivitas ASN dalam melayani pemadam kebakaran pada UPTD Pemadam Kebakaran Kota Bogor sudah sangat responsif dalam penanganan pelayanan bencana kebakaran di Kota Bogor. Hal ini dapat dilihat dari berbagai indikator pengukuran responsivitas yang ditemukan penulis di lapangan, bahwa dari seluruh pengukuran indikator responsivitas yang digunakan hanya pada indikator pertama yang mencakup sikap petugas pelayanan pemadam kebakaran yang dikategorikan baik dalam melayani permintaan masyarakat. Tetapi angka rata rata yang didapat yaitu sebesar 3,96 dengan kategori baik dan belum sempurna, berarti didalamnya masih terdapat kekurangan dan hambatan didalam memberikan pelayanan.

Berdasarkan kesimpulan diatas, peneliti dapat memberikan beberapa saran yang diharapkan dapat menjadi masukan untuk semakin meningkatkan responsivitas pelayanan pemadam kebakaran pada UPTD Pemadam Kebakaran Kota Bogor, antara lain:

1. Peningkatan lagi didalam informasi teknologi (IT) dengan dibuatkan website sendiri dimana diaplikasi ini terdapat peta rawan bencana dan layanan pengaduan langsung dari masyarakat, dimana masyarakat bisa menyampaikan kritikan dan saran langsung ke pemadam kebakaran.

2. Kerjasama selain dengan instansi, masyarakat juga pihak swasta.

3. Terus melakukan sosialisasi terhadap masyarakat pentingnya pencegahan dan penanggulangan kebakaran sejak dini.

Penelitian ini telah membuktikan bahwa kinerja petugas pemadam kebakaran berhubungan dengan beberapa faktor internal dan eksternal. Peningkatan kinerja petugas pemadam kebakaran akan sebanding dengan peningkatan faktor-faktor yang berkaitan. Faktor yang berhubungan dengan kinerja ASN dalam penelitian ini adalah motivasi berprestasi, disiplin kinerja. Hal ini sejalan dengan pendapat Hasibuan (2000:87) mempengaruhi kinerja antara lain:

(1) sikap mental/motivasi kerja,

(2) disiplin kerja,

(3) etika kerja);

(4) pendidikan;

(5) keterampilan;

(6) manajemen kepemimpinan;

(7) tingkat penghasilan;

(8) gaji dan kesehatan;

(9) jaminan sosial;

(10) iklim kerja;

(11) sarana pra sarana;

(12) teknologi; 
(13) kesempatan berprestasi

\section{DAFTAR PUSTAKA}

Badu, Ahmad, 2013. Manjemen

Pelayanan Publik, Makassar:

Andi Offset.

Dwiyanto, Agus, 2006. Mewujudkan Good

Governance melalui

Pelayanan Publik. Yogyakarta:

Gadjah Mada University Press.

Tjiptono, Fandy,Ph.D, 2016. Service

Quality dan Satisfaction. Yogjakarta:

Andiooffset

Hardyansah, 2011. Kualitas Pelayanan

Publik. Yogyakarta: Gava Media.

Harbani, 2012. Metode Penelitian Administrasi Publik. Bandung: Alfabeta

Ibrahim, Amin, 2008. Teori dan Konsep Pelayanan Publik serta

Implementasinya. Bandung: Bandar Maju.

Moleong, Lexy J, 2007. Metodologi Penelitian Kualitatif. Bandung: Rosda

Nasucha, Chaizi. 2004. Reformasi Administrasi Publik Teori dan Praktek.

Jakarta: PT. Grasindo Anggota Ikapi

Nurmandi, Achmad. 2010. Manajemen Pelayanan Publik. Yogyakarta: PT.

Sinergi Visi utama

Pasolong, Harbani. 2007. Teori Administrasi Publik. Bandung: Afabeta

Pasolong, Harbani. 2012. Metode Penelitian Administrasi Publik. Bandung:

Alfabeta

Ramli, Soehatman. 2010. Petunjuk Praktis Manajemen Kebakaran. Jakarta:

Dian Rakyat

Ratminto dan Atik Septi Winarsih. 2005. Manajemen Pelayanan.

Yogyakarta: Pustaka Pelajar

Rohman, Ahmad Ainur. 2010. Reformasi Pelayanan Publik. Malang: Averroes Press

Sedarmayanti. 2004. Good Governance (Kepemerintahan yang baik) bagian kedua. Bandung: Mandar Maju
Pengaruh Kualitas Pelayanan Terhadap Kepuasan

Masyarakat Pada Pembuatan Kartu Peserta JKN

Sedarmayanti. 2007. Good Governance

(Kepemerintahan yang baik dan

Good Corporate Governance (Tata kelola Perusahaan yang baik) Bagian ketiga. Bandung: Mandar

Maju

Sentosa, Pandji. 2008. Administrasi

Publik Teori dan Aplikasi Good

Governance. Bandung: Refika

Adiatma

Sinambela, Lijan P dkk. 2006. Reformasi

Birokrasi. Jakarta: Bumi Aksara

Sugandi, Yogi Suprayogi. 2011.

Administrasi Publik Konsep dan

Perkembangan Ilmu di Indonesia.

Bandung: Graha Ilmu

Sugiyono. 2010. Metode Penelitian

Administrasi. Bandung: Alfabeta

Sugiyono. 2011. Metode Penelitian

Kuantitatif Kualitattif dan R\&D.

Bandung: Alfabeta

\section{Peraturan- peraturan :}

Undang-undang Nomor 25 tahun 2009 tentang pelayanan publik

Undang-undang Nomor 24 Tahun2007 tentang Penanggulangan Bencana

Peraturan Menteri Pekerjaan Umum Nomor 20 tahun 2009 tentang Pedoman teknis Manajemen Proteksi Kebakaran di Perkotaan.

\section{Website :}

http:/www.kompasiana.com/bellanurfiani /kebakaran-di-kelurahan-

gudang_552a6a14e61cc09d623ec

Alat Pemadam Kebakaran. Klasifikasi Jenis Penyebab Kebakaran. http://www.alat-pemadamkebakaran.co.id/klasifikasi-jenispenyebab-kebakaran/. (Diakses pada 1 November 2015 Pukul 21.35 WIB )

Psychoshare. Psikologikepribadian/sikap pengertian definisi dan faktor yang mempengaruhi.http://www.psychoshare.c om/file - $\quad$ 821/psikologikepribadian/sikap-pengertian-definisidan-faktor-yang-mempegaruhi.html. Diakses pada 15 Februari 2016 pukul 18.30 
Wita (diakses pada 15 Febuari 2016 pada pukul 18.50 WIB)

http://ejournal.unesa.ac.id/index.php/publ $\underline{\mathrm{ika} / \text { article/view/13710/17590 }}$

Ika Widianati,2015."Responsivitas pelayanan publik dalam menangani keluhan pelanggan publik.(diakses pada 15 Febuari 2016 pada pukul 18.50 WIB) 